\title{
Molecular detection and genomic characterisation of Torque teno canis virus in Turkey
}

\author{
Turhan Turan, Hakan Işıdan*, and Mustafa Ozan Atasoy \\ Virology Department, Faculty of Veterinary Medicine, Sivas Cumhuriyet University, \\ Sivas, Turkey
}

TURAN, T., H. IŞIDAN, M. O. ATASOY: Molecular detection and genomic characterisation of Torque teno canis virus in Turkey. Vet. arhiv 90, 467-475, 2020.

\section{ABSTRACT}

Torque teno virus (TTV) was first detected in humans, and since then it has been reported in many host species, such as monkeys, cats, pigs, seagulls and dogs. The aim of this study was to investigate the presence of Torque teno canis virus (TTCaV) in shelter dogs housed in Sivas Municipal Animal Shelter, Turkey. Faecal specimens, including diarrheic and non-diarrheic $(n=202)$, were collected from dogs of various age groups. In total, $32.18 \%(65 / 202)$ of samples were found positive for TTCaV. Out of the 65 positive samples, $34.64 \%(44 / 127)$ samples were from adult diarrheic dogs and $26.09 \%(6 / 23)$ belonged to diarrheic puppies. On the other hand, $28.84 \%(15 / 52)$ positive samples were detected from clinically healthy dogs. Eight sequences showed close homology among themselves, however, the sequences of two samples (CANEL130 and CANEL140) were genetically distinct from other published sequences. This is the first report on the detection of TTCaV in adult dogs and puppies in Turkey, and provides evidence that $\mathrm{TTCaV}$ cannot be considered as the sole cause of diarrhea.

Key words: shelter dogs; Torque teno canis virus; Turkey

\section{Introduction}

Torque teno virus (TTV) was first isolated from a human patient, who clinically developed hepatitis after a blood transfusion (NISHIZAWA et al., 1997). Human torque teno virus is a prototype of the Anelloviridae family. Anelloviruses contain circular, single stranded DNA, which is $2.1-3.8$ $\mathrm{kb}$ in length, and morphologically appear as small, non-enveloped particles of approximately 30-32 $\mathrm{nm}$ in size. The Anelloviridae family is divided into 14 genera, each containing a large number of species, due to high-level genetic heterogeneity.
Anelloviruses have been reported to be widespread all over the world (ICTV 2018 https://talk. ictvonline.org/taxonomy/; MANZIN et al., 2015).

Torque teno canis virus (TTCaV) is a member of the genus Thetatorquevirus. The presence of TTCaV was first discovered by OKAMOTO et al. (2002). Recently, a metagenomic study on Rhipicephalus ticks revealed a novel virus, the Nayun tick torquevirus, showing $42.79 \%$ nucleotide identity with TTCaV and it was also classified in the Thetatorquevirus genus (XIA et al., 2015).

\footnotetext{
*Corresponding author:

Hakan Işıdan, Virology Department, Faculty of Veterinary Medicine, Sivas Cumhuriyet University, Sivas, 58140 Sivas,Turkey, E-mail: hisidan@ cumhuriyet.edu.tr
} 
A typical TTCaV genome contains three major open-reading frames (ORF1, ORF2 and ORF3), a guanine-cytosine (GC)-rich region (up to $90 \%$ ) and a short untranslated region (UTR) (MARTÍNEZ et al., 2006). Despite the fact that TTV was first identified in a patient with cryptogenic hepatitis, subsequent studies have not provided evidence that TTV plays an important role in the pathogenesis of hepatitis or other diseases (OKAMOTO, 2009). However, it has been experimentally demonstrated that TTV co-infection with porcine reproductive and respiratory syndrome virus partially contributes to the stimulation of swine dermatitis and nephropathy syndrome (ZHANG et al., 2012).

The pathogenic role of $\mathrm{TTCaV}$ in causing infection is unclear due to the very limited reports about its mechanism of pathogenicity, and its association in co-infection with other pathogens has not yet been investigated (SUN et al., 2017). In Turkey, the presence of TTV in human individuals with or without chronic hepatitis B, has been previously reported (KASIRGA et al., 2005; ODEMIS et al., 2004). However, there have been no reports about the detection of TTV in animals in the country. This is the first report about the prevalence of TTCaV in canine species in Turkey.

\section{Materials and methods}

Samples and DNA isolation. In the present study, a total of 202 rectal swab specimens were collected from 1100 dogs in Sivas Municipality Animal Shelter. A total of 150 dogs manifested symptoms of gastrointestinal infection, including adult dogs of 1 year old $(n=127)$ and puppies 2-4 months old $(n=23)$; whereas 52 adult dogs were clinically healthy. Samples were transported in cold chain to the laboratory immediately after sampling, and stored at $-80{ }^{\circ} \mathrm{C}$ until further processing.

Faecal samples were diluted 1:10 with $1 \mathrm{M}$ phosphate buffered saline, and centrifuged for 10 min at 3,500 rpm to remove large cellular debris. The collected supernatants were used for nucleic acid extraction using a GF-1 Viral Nucleic Acid Extraction Kit, according to the manufacturer's instructions (Vivantis Technologies, Malaysia). Eluted nucleic acids were stored at $-80{ }^{\circ} \mathrm{C}$ until further use.
Specific PCR for TTCaV DNA detection. In our study, a set of primers were designed for nested PCR from the ORF3/ORF1 region: TTCaV 2158F (5'-ACCAGCACCCACATTGACAA-3') and TTCaV 2567R (5'-TTTAGAAGGGCCAGC AGTCC-3') for the first round of amplification. In the second round of amplification, TTCaV 2165Fn (5'CCCA CATTGACAACCCWTGC-3') and TTCaV 2460Rn (5'-GTGGTCCTCCTCCTCTTCCT-3') were used for detection of the virus. The PCR mixture was prepared as a $50 \mu \mathrm{L}$ final volume containing $5 \mu \mathrm{L}$ template, $5 \mu \mathrm{L}$ of $10 \times$ PCR buffer, $10 \mathrm{mM}$ of dNTP, $10 \mathrm{pmol} / \mu \mathrm{L}$ of each set of sense/ antisense primers, and $5 \mathrm{U}$ of Taq DNA polymerase (Vivantis, Germany). For both rounds of the PCR, the thermal cycling conditions consisted of predenaturation at $95^{\circ} \mathrm{C}$ for 2 minutes, followed by 40 cycles of denaturation at $94^{\circ} \mathrm{C}$ for $45 \mathrm{sec}$, annealing at $53{ }^{\circ} \mathrm{C}$ (the first round) and $55^{\circ} \mathrm{C}$ (second round) for $45 \mathrm{sec}$, Extension at $72{ }^{\circ} \mathrm{C}$ for $1 \mathrm{~min}$. Final extension was kept at $72{ }^{\circ} \mathrm{C}$ for $10 \mathrm{~min}$. A $1 \mu \mathrm{L}$ aliquot from the first round of PCR was used in the second reaction. PCR products were separated by electrophoresis in $1.5 \%$ agarose gels stained with ethidium bromide. The 296 bp PCR amplicons from second round reactions were confirmed under the gel documentation system (BioRad, USA).

Sequencing and phylogenetic analysis. The PCR amplicons were purified with the Wizard SV Gel and PCR Clean-Up System (Promega, USA) and sequenced using the BigDye Terminator Cycle Sequencing Kit (Applied Biosystems, USA) on an ABI 3100 automated sequencer (Applied Biosystems, USA). Nucleotide sequences successfully amplified for this study were deposited in the GenBank database and accession numbers were given between MK496298 and MK496307.

All sequenced products were used to construct phylogenetic data, and for deduction of amino acid sequences. Partial sequences of the ORF3/ORF1 gene were compared with other torque teno virus sequence data available in the National Center for Biotechnology Information (NCBI: https://www. ncbi.nlm.nih.gov/) database. Sequence alignment and phylogenetic analysis were drawn with GENEIOUS PRIME software version 2019.2.1 (https://www.geneious.com). The neighbor-joining 
method and the Tamura-Nei genetic distance model (TAMURA and NEI, 1993) were used to build the tree. The tree was drawn to scale, with branch lengths measured as the number of substitutions per site, and it was bootstrapped with 1000 replicates.

\section{Results}

TTCaV DNA prevalence in dog feces. A total of $65(32.18 \%)$ out of 202 samples were found to be positive for TTCaV by nested PCR. Out of 150 diarrheic dogs, 50 samples were positive for TTCaV (33.33\%). This included 44 out of 127 adult dogs $(34.64 \%)$ and 6 out of 23 puppies $(26.09 \%)$. Out of the 52 healthy adult dogs, $15(28,84 \%)$ were also found positive. However, Chisquare analysis revealed non-significant differences $(p>0.05)$ in the distribution of $\mathrm{TTCaV}$ cases between healthy and diarrheic dogs.

Assessment of genetic diversity. The $296 \mathrm{bp}$ nucleotide and 98 amino acid (aa) sequences of the ORF3/ORF1 gene obtained from ten samples were compared among themselves and with nine genomic sequences retrieved from the NCBI GenBank database. Analysis of multiple sequence alignment revealed that eight of ten partial sequences of our study showed $97.31 \%$ to $100 \%$ nucleotide and $92.86 \%$ to $100 \%$ amino acid similarity with other available GenBank sequences. The sample CANEL112 sequence in our study showed 100\% nucleotide and aa sequence homology to two Chinese isolates GX206 (KX827767) and GX249 (KX827768). However, two isolates in our study (CANEL130 and CANEL140) displayed close identity between each other $(97.97 \%$ nucleotide and $96.94 \%$ aa), but relatively low sequence homology with other samples $(88.18 \%$ to $91.55 \%$ nucleotide and $79.59 \%$ to $83.67 \%$ aa).

The 296 bp sequence data obtained using nested primer pairs of TTCaV $2158 \mathrm{~F} / 2567 \mathrm{R}$ and $\mathrm{TTCaV}$ $2165 \mathrm{Fn} / \mathrm{TTCaV} 2460 \mathrm{Rn}$ were compared among themselves and with the present data in GenBank. Analysis of the multiple sequence alignment of the partial ORF3/ORF1 regions' nucleotide and aa translations revealed that several mutations resulted in amino acid variations at multiple positions (See Figs. 1, 2 and 3.)
Phylogenetic analysis of ORF3/ORF1 nucleotide sequences revealed two clades, with group classification similar to that identified from the multiple sequence alignment analysis, as shown in Fig. 1 and 2. Clades were well supported by bootstrap values for each nodes (See Fig. 4).

\section{Discussion}

Torque teno virus (TTV) can infect many host species, including humans (KASIRGA et al., 2005; ODEMIS et al., 2004), and animals such as pigs (LEE et al., 2012; XIA et al., 2015), nonhuman primates (OKAMOTO et al., 2001), marine mammals (NG et al., 2009), cattle and sheep (BIAGINI, 2009). Torque teno virus (TTV) was first described in dogs in Japan (OKAMOTO et al., 2002), and since then a few cases have been reported from China and Brazil (LAN et al., 2011; SUN et al., 2017; WEBER et al., 2018). In our study, a total of $32.18 \%$ samples were positive for TTV. The prevalence of TTV virus in specimens from dogs with abnormal fecal appearance was reported as 13\% in China (LAN et al., 2011). Another study from China reported 7\% prevalence of TTCaV in serum samples of clinically healthy dogs (SUN et al., 2017). On the other hand, three out of eight clinically healthy dogs $(38 \%)$ were detected to be positive in Japan (OKAMOTO et al., 2002). Although there are differences in sampling size, the findings of our study are concordant with the study reported from Japan, However, the prevalence of TTCaV in Turkey was relatively higher than the reports from China. Considering the studies reported from China, our study revealed a considerably higher percentage of prevalence in both diarrheic and clinically healthy dogs, including adult dogs and puppies. Epidemiological differences may be associated with sampling and geographical variations

Multiple sequence alignment of ORF3/ORF1 revealed amino acid sequence differences at multiple positions (29/98 substitutions). Despite amino acid chain similarity between the reference sequence (NC_014071.1) and the general tendency of Turkish samples ranging between 93.88 to 96.94\%, CANEL130 and CANEL140 presented a relatively lower percentage of similarity, 79.59 and $81.63 \%$, respectively (Fig. 2). 

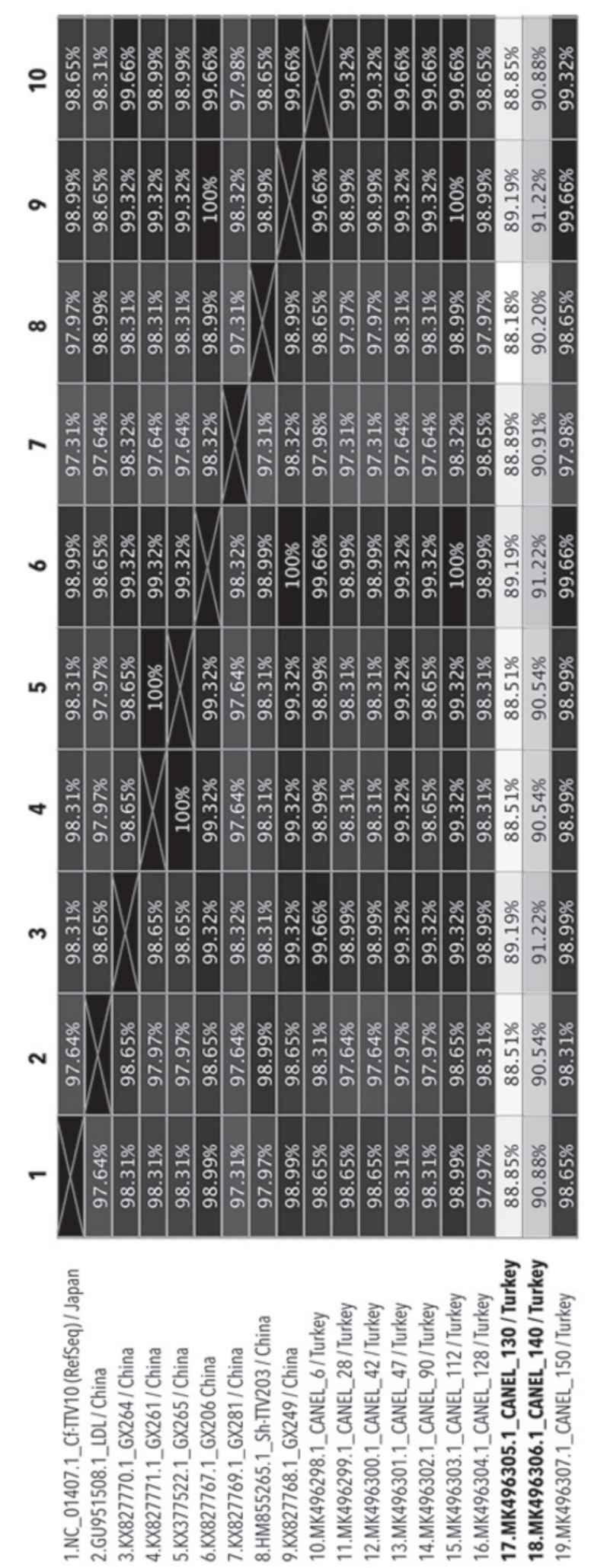

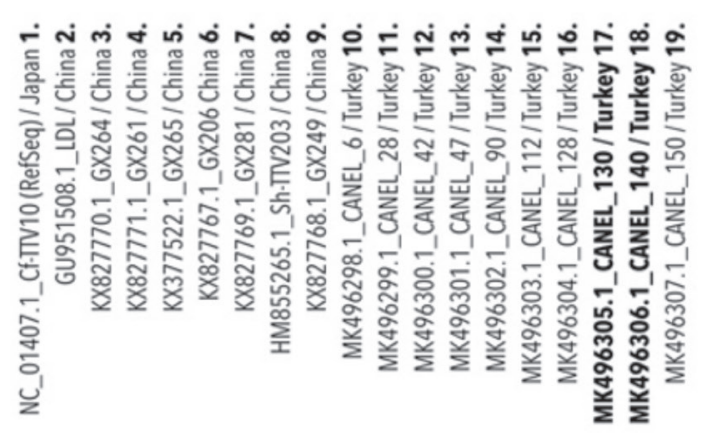

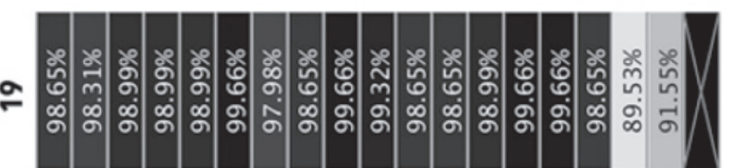

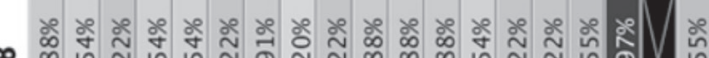
बूं ूँ

议

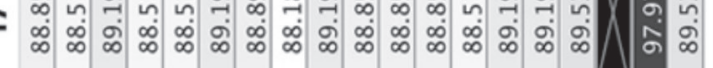

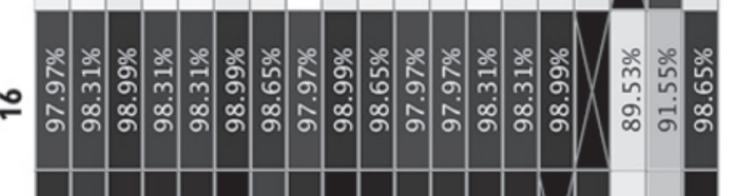

హ。

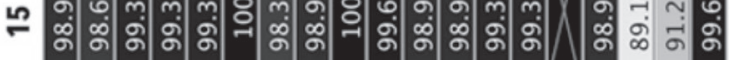

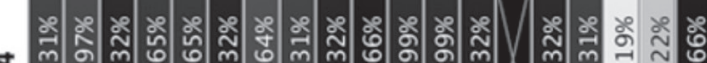

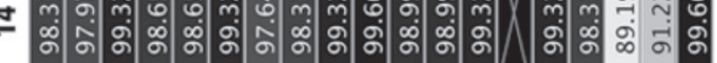

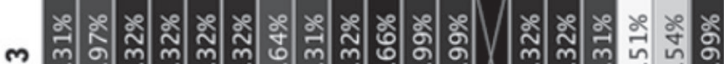

$m$

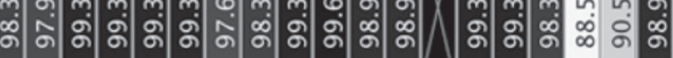

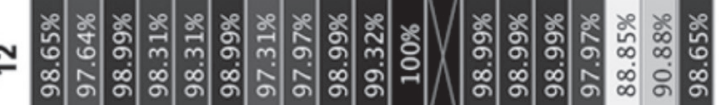

孚

总

을

วิ

ำ

D

$\frac{\mathscr{d}}{\frac{\pi}{0}}$

$i_{\pi}^{\infty}$

点

离

公

葛

.

$\frac{0}{0}$

-

我

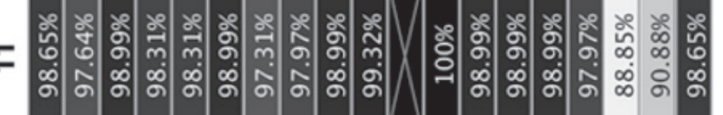



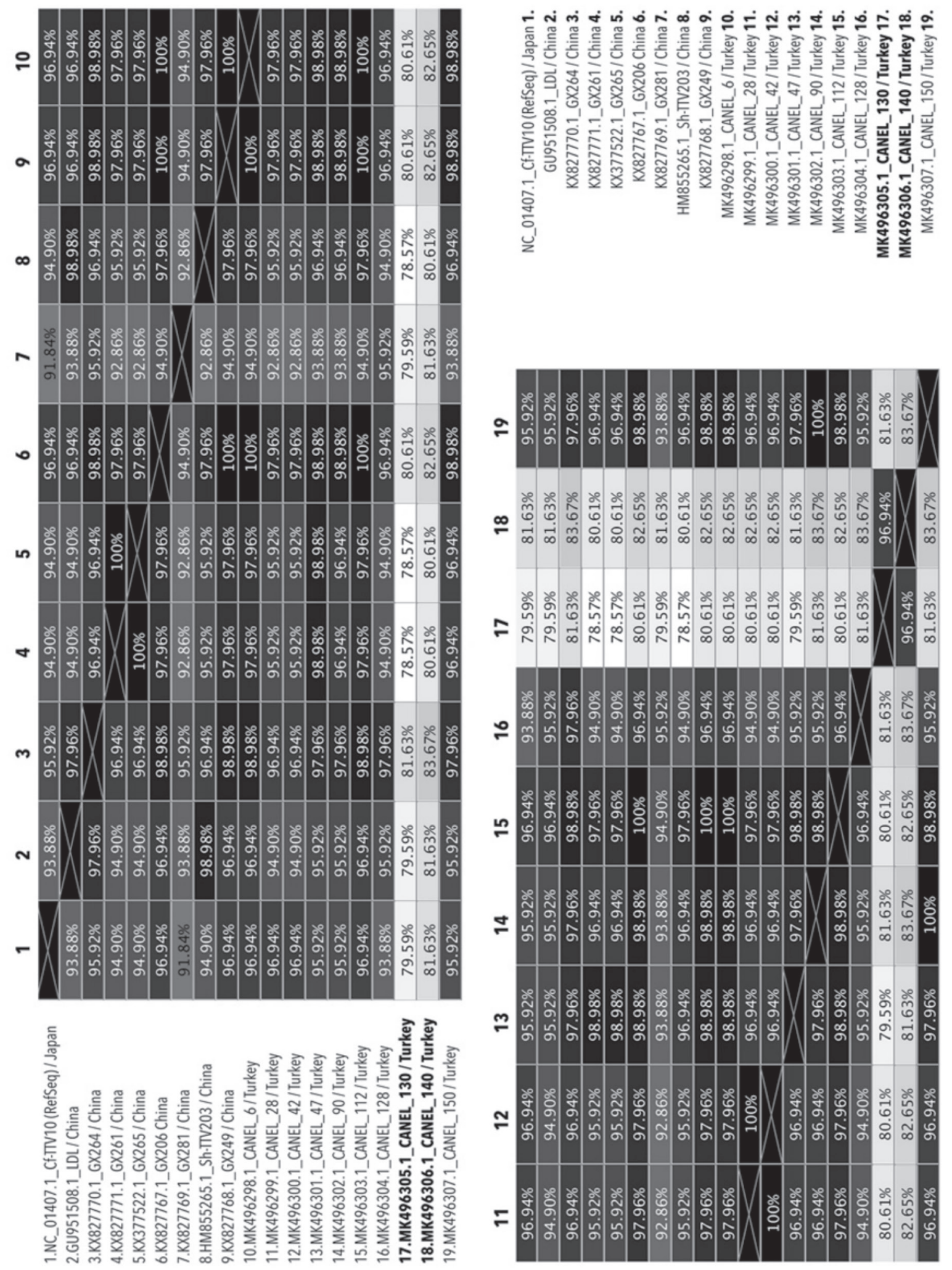

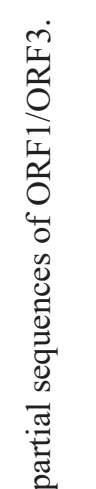

உ

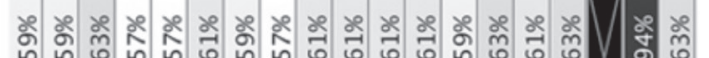

レ হ হं

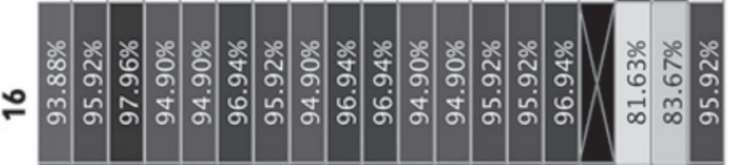

ᄂ

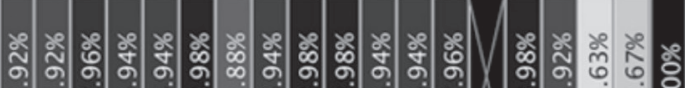

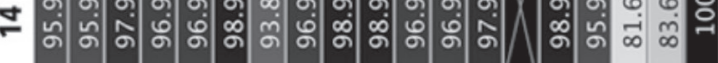

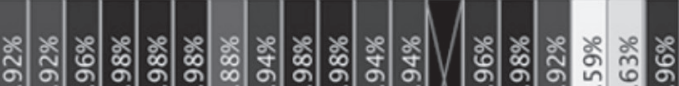

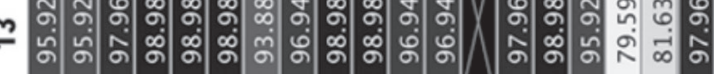

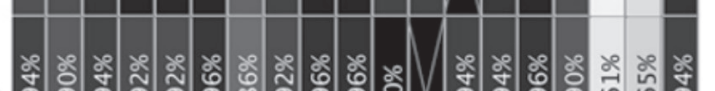

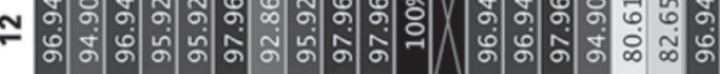

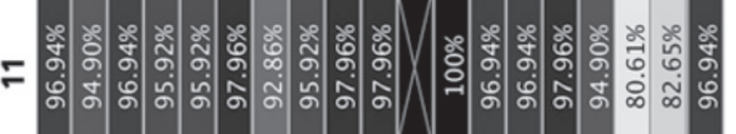


T. Turan et al.: Molecular detection and genomic characterisation of Torque teno canis virus in Turkey

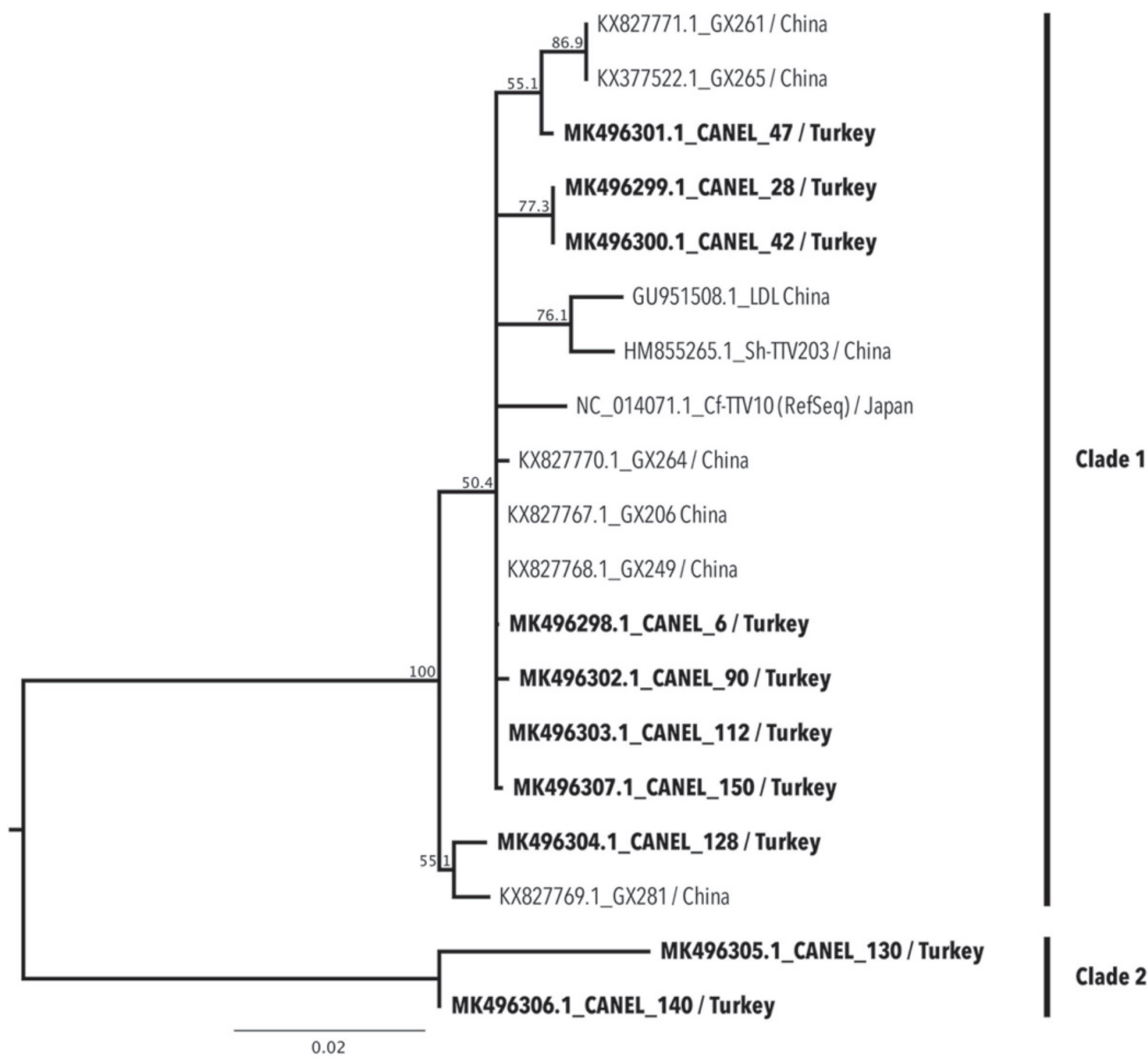

Fig. 3. Multiple alignment of 98 aa partial sequences of the ORF1/ORF3 region of TTCaV isolates. 
T. Turan et al.: Molecular detection and genomic characterisation of Torque teno canis virus in Turkey

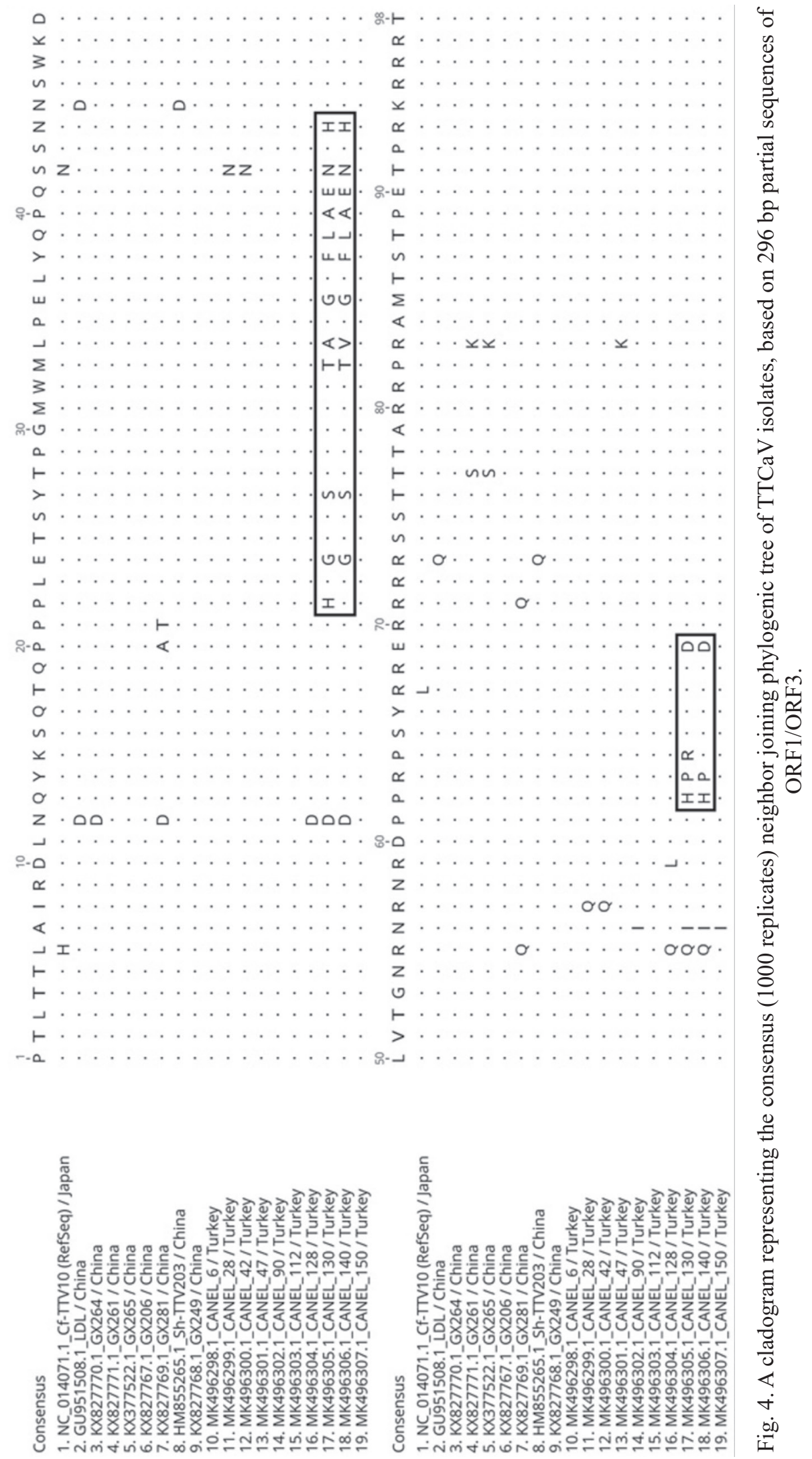


Indeed, further investigations must be undertaken to determine the reasons of divergence in the two sequences obtained in this study. However, analysis of partial sequences, both nucleotide and amino acids, clearly indicates two distinct sub-genotypes of $\mathrm{TTCaV}$, even if they are a small part of the genome (Figs 2, 3, 4).

In conclusion, our study provides the first information on the prevalence of $\mathrm{TTCaV}$ in both clinically healthy and diarrheic dogs in Turkey, and reveals the partial genomic sequence data from canine faecal samples. We found no correlations in the presence of TTCaV in terms of age or health condition. Therefore, we are of the opinion that TTCaV cannot be considered as a cause of diarrhea. On the basis of the phylogenetic analysis, we propose that the two isolates of our study are new genotypes of Torque teno canis virus. The present study is also one of the pioneer studies revealing the existence of TTCaV, after the reports from Japan, China and Brazil. The findings of our study may be used as an indication to compare with future studies for the presence of canine TTV worldwide.

\section{References}

BIAGINI, P. (2009): Classification of TTV and related viruses (anelloviruses). In: TT Viruses, Current Topics in Microbiology and Immunology, vol 331. (de Villiers E. M., H. Hausen, Eds.), Springer, Berlin, Heidelberg, pp. 21-33.

KASIRGA, E., T. SANLIDAG, S. AKCALI, S. KESKIN, E. AKTAS, Z. KARAKOC, M. HELVACI, G. SOZEN, G. KUZU (2005): Clinical significance of TT virus infection in children with chronic hepatitis B. Pediatr. Int. 47, 300304.

DOI: $10.1111 / \mathrm{j} .1442-200 x .2005 .02053 . x$

LAN, D., X. HUA, L. CUI, X. LUO, Z. LIU, T. SAN, C. X. ZHU, W. ZHAO, Z. YANG (2011): Sequence analysis of a Torque teno canis virus isolated in China. Virus Res. 160, 98-101.

DOI: 10.1016/j.virusres.2011.05.017

LEE, S., J. SHIN, C. KIM, Y. S. LYOO (2012): Comparison of Torque Teno Sus Virus (TTSuV) viral load in Porcine Circovirus Type 2 vaccinated and non-vaccinated pig herds. Res. Vet. Sci. 93, 1039-1041.

DOI: 10.1016/j.rvsc.2011.10.021

MANZIN, A., F. MALLUS, L. MACERA, F. MAGGI, S. BLOIS (2015): Global impact of Torque teno virus infection in wild and domesticated animals. J. Infect. Dev. Ctries. 9, 562-570.

DOI: $10.3855 /$ jidc. 6912
MARTÍNEZ, L., T. KEKARAINEN, M. SIBILA, F. RUIZFONS, D. VIDAL, C. GORTÁZAR, J. SEGALÉS (2006): Torque teno virus (TTV) is highly prevalent in the European wild boar (Sus scrofa). Vet. Microbiol. 118, 223-229.

DOI: 10.1016/j.vetmic.2006.07.022

NG, T. F. F., W. K. SUEDMEYER, E. WHEELER, F. GULLAND, M. BREITBART (2009): Novel anellovirus discovered from a mortality event of captive California sea lions. J. Gen. Virol. 90, 1256-1261.

DOI: 10.1099/vir.0.008987-0

NISHIZAWA, T., H. OKAMOTO, K. KONISHI, H. YOSHIZAWA, Y. MIYAKAWA, M. MAYUMI (1997): A novel DNA virus (TTV) associated with elevated transaminase levels in posttransfusion hepatitis of unknown etiology. Biochem. Biophys. Res. Commun. 241, 92-97.

DOI: 10.1006/bbrc.1997.7765

ODEMIS, E., F. GURAKAN, K. ERGUNAY, A. YUCE, H. OZEN, N. KOCAK (2004): TTV infection in children with and without liver disease. Indian. J. Gastroenterol. 23, 135137.

OKAMOTO, H. (2009): TT viruses in animals. In: TT Viruses. Current Topics in Microbiology and Immunology, vol 331. (de Villiers E. M., Hausen H. Eds): Springer, Berlin, Heidelberg, pp. 35-52.

OKAMOTO, H., T. NISHIZAWA, M. TAKAHASHI, A. TAWARA, Y. PENG, J. KISHIMOTO, Y. WANG (2001): Genomic and evolutionary characterization of TT virus (TTV) in tupaias and comparison with species-specific TTVs in humans and non-human primates. J. Gen. Virol. 82, 2041-2050.

DOI: 10.1099/0022-1317-82-9-2041

OKAMOTO, H., M. TAKAHASHI, T. NISHIZAWA, A. TAWARA, F. KATSUHIKO, U.MURAMATSU, Y.NAITO, A. YOSHIKAWA (2002): Genomic characterization of TT viruses (TTVs) in pigs, cats and dogs and their relatedness with species-specific TTVs in primates and tupaias. J. Gen. Virol. 83, 1291-1297.

DOI: 10.1099/0022-1317-83-6-1291

SUN, W., C. XIE, C. LIANG, M. ZHENG, G. ZHAO, P. ZHANG, J. HAN, J. JING, S. WEN, P. XIAO, Z. CUI, J. ZHANG, J. REN, H. LIU, H. LU, N. JIN (2017): Molecular detection and genomic characterization of Torque teno canis virus in domestic dogs in Guangxi Province, China. J. Biotechnol. 252, 50-54.

DOI: 10.1016/j.jbiotec.2017.05.003

TAMURA, K., M. NEI (1993): Estimation of the number of nucleotide substitutions in the control region of mitochondrial DNA in humans and chimpanzees. Mol. Biol. Evol. 10, 512-526.

DOI: 10.1093/oxfordjournals.molbev.a040023

WEBER, M. N., S. P. CIBULSKI, J. C. OLEGÁRIO, M. S. da SILVA, D. E. PUHL, A. C. S. MÓSENA, C. D. B. T. ALVES, W. P. PAIM, L. F. BAUMBACH, F. Q. MAYER, 
A. R. F. FERNANDES, S. S. AZEVEDO, C. W. CANAL (2018): Characterization of dog serum virome from Northeastern Brazil. Virology. 525, 192-199.

DOI: $10.1016 /$ j.virol.2018.09.023

XIA, H., C. HU, D. ZHANG, S. TANG, Z. ZHANG, Z. KOU, FAN, D. BENTE, C. ZENG, T. LI (2015): Metagenomic profile of the viral communities in Rhipicephalus spp. ticks from Yunnan, China. PLoS ONE. 10, e0121609.

DOI: 10.1371/journal.pone.0121609
ZHANG, Z., Y. WANG, H. FAN, C. LU (2012): Natural infection with torque teno sus virus 1 (TTSuV1) suppresses the immune response to porcine reproductive and respiratory syndrome virus (PRRSV) vaccination. Arch. Virol. 157, 927-933.

DOI: $10.1007 / \mathrm{s} 00705-012-1249-3$

Received: 12 September 2019

Accepted: 8 May 2020

TURAN, T., H. IŞIDAN, M. O. ATASOY: Molekularno otkrivanje i genomska svojstva psećeg virusa Torque teno u Turskoj. Vet. arhiv 90, 467-475, 2020.

\section{SAŽETAK}

Virus Torque teno (TTV) otkriven je najprije u ljudi, no otada je zabilježen i u mnogim drugim domaćinima kao što su majmuni, mačke, svinje, galebovi i psi. Cilj ovoga rada bio je istražiti prisutnost psećeg virusa Torque teno $(\mathrm{TTCaV})$ u pasa u azilu Sivas Municipal Animal Shelter u Turskoj. Uzorci izmeta $(\mathrm{n}=202)$, uključujući one s proljevom i bez proljeva, prikupljeni su od pasa različitih dobnih skupina. Ukupno je 32,18 \% (65/202) uzoraka bilo pozitivno na TTCaV. Od 65 pozitivnih uzoraka njih 34,64\% (44/127) potjecalo je od odraslih pasa s proljevom, a $26,09 \%(6 / 23)$ od štenadi s proljevom. S druge strane, $28,84 \%(15 / 52)$ pozitivnih uzoraka utvrđeno je u klinički zdravih pasa. Osam je sekvencija pokazalo međusobnu blisku srodnost, no sekvencije dvaju uzoraka (CANEL130 i CANEL140) genetski su se razlikovale od drugih sekvencija. Ovo je prvi nalaz TTCaV u odraslih pasa i štenadi u Turskoj i dokazuje da se TTCaV ne može smatrati jedinim uzročnikom proljeva.

Ključne riječi: psi iz azila; virus Torque teno canis; Turska 
